\title{
Two Stay Two Stray Model Providing Mind Mapping Influences on the Learning Outcomes of Grade V SD Students
}

\author{
Mona Ratuliu Nadapdap ${ }^{1 *}$, Ni Wayan Arini ${ }^{1}$, Luh Putu Putrini Mahadewi ${ }^{2}$ \\ ${ }^{1}$ Primary School Teacher Education Study Program, Universitas Pendidikan Ganesha, Indonesia \\ ${ }^{2}$ Educational Technology Study Programs, Universitas Pendidikan Ganesha, Indonesia \\ "Corresponding author. Email: mratuliunadapdap@gmail.com
}

\begin{abstract}
This The low science learning outcome of grade V SD Gugus I, Buleleng District was the main reason for this research. This study aims to determine the effect of the two stay two stray learning model providing mind mapping on the science learning outcomes of fifth-grade students of SD Gugus I, Buleleng District, Buleleng Regency, 2019/2020 academic year. This research is a quasi-experimental research type and uses a non-equivalent post-test only control group design experiment. The population in this study were 180 students in 6 classes of class V. Determination of the sample using simple random sampling technique in order to obtain class V SDN 5 Banyuning as the experimental class and SDN 6 Banyuning as the control class. Data were collected using a multiple-choice test method. The results of the calculations show that the average science learning outcomes of the experimental group students are higher than the control group. The data obtained were analyzed using descriptive statistical analysis and inferential statistics. Based on the hypothesis test, it was obtained that count 5.21 was greater than ttable 2.02, thus it was concluded. Thus it can be concluded that there was an effect on the use of the tsts learning model providing mind mapping on students of class V SDN in Cluster I Buleleng District, Buleleng Regency Academic Year 2019/2020. This research as a whole has a positive impact on students. Students become more active, have high self-confidence, and are able to establish good interactions between fellow students.
\end{abstract}

Keywords: Learning outcome, TSTS, Mind Mapping

\section{INTRODUCTION}

Learning and learning become a series of activities that cannot be separated. Learning is a term to indicate the activities of teachers and students. The term learning is a translation of the word "instruction". According to Gagne, et al [1] learning is a series of activities designed to enable the learning process to occur in students. The word or term learning has become popular since the National Education System Law No. 20 of 2003 [11]. According to this law, learning is defined as a process of interaction between students, educators, and learning resources in a learning environment. The term learning refers to all activities that have a direct effect on the learning process of students.

Improving and supporting the learning process of students is the main feature of learning. This shows that the deliberate element of those outside the individual who carries out the learning process is the main feature of the learning concept. In addition, interaction is also a feature of learning activities. This interaction occurs between students who learn and their learning environment, both with teachers, with other students, tutors, media, or other learning resources. Another feature of learning is the components that are related to one another. These components are the objectives, materials, activities, and evaluation of learning. Learning objectives refer to the abilities that students are expected to have after participating in certain learning. Learning material is expected to be owned by students after participating in certain learning. Learning material is everything that is discussed in learning in order to achieve predetermined goals. Learning activities refer to the use of methods and media in order to discuss material so that learning objectives can be maximally achieved. Evaluation is an activity carried out to assess the success of learning. 
The purpose of learning is to encourage students to be more active and creative in various situations. This is in accordance with the learning objectives in the 2013 curriculum, namely learning that is centered on students and provides a stimulus for them to think more creatively, innovatively, actively, and responsively to the situations they face. The ultimate goal of this curriculum is to prepare a generation of Indonesians who are faithful, productive, innovative, and of course have a good impact on people's lives. Learning in this curriculum is thematic learning with a scientific approach. The subject matter includes Indonesian, Science, Social Sciences, PPKn, SBdP, Mathematics and PJOK.

The science material in the 2013 curriculum includes four core competencies, namely 1) accepting, implementing, and respecting the teachings of the religion they adhere to, 2) demonstrating honest, disciplined, responsible, polite, confident, caring and responsible behavior in interacting with family, friends, neighbors and countries, 3) understand factual, conceptual, procedural, metacognitive knowledge at the basic level by observing, questioning and trying based on curiosity about himself, God's creatures and their activities, and objects he finds at home, at school, and playground. 4) Shows creative, productive, critical, independent, collaborative, and communicative thinking and action skills. In clear, systematic, logical, and critical language, in aesthetic works, in movements that reflect a healthy child, and in actions that reflect children's behavior according to their developmental stage.

In addition, the desired achievements through learning science are 1) gaining confidence in the greatness of God Almighty based on the existence, beauty, and natural order of His creation, 2) developing knowledge and understanding of science concepts that are useful and can be applied in everyday life, 3) develop curiosity, positive attitude, and awareness of the interplay between science, environment, technology and society, 4) develop process skills to investigate the surrounding environment, solve problems and make decisions, 5) increase awareness to participate in maintaining, preserving and preserving the natural environment, 6) increasing awareness to respect nature and all its regularities as God's creation, and 7) obtaining knowledge, concepts, and science skills as a basis for continuing education to the next level. Science is mostly mental activity and human practice to generate knowledge. Knowledge is conveyed as a goal, able to produce the highest truth, able to prove something, has a set subject matter and this has a unique method and value of freedom [2].

So it can be concluded that natural science is the study of the natural surroundings related to how to find out about nature systematically, so that natural science is not only the mastery of a collection of knowledge in the form of facts, concepts, or principles but also a process of discovery. which will be developed into new and useful knowledge. Therefore science really needs to be taught properly and involve students actively in learning activities. This learning will be achieved if there is correct cooperation between teachers and students. Thus, science learning will materialize and become meaningful learning.

Based on the results of interviews conducted in class $\mathrm{V}$ at SD Gugus I, Buleleng District, Buleleng Regency on October 19-20, the problems experienced by students were: (1) most of the material being studied was memorizing, (2) the teacher's busyness, causing a lack of preparation for classroom learning. In addition, observation activities were also carried out on 21-22 October 2019 to find several problems that occurred during the learning process, while the results were (1) students were less active in learning (2) the level of students' understanding of the material being taught was still low, so that has an impact on learning outcomes, (3) the lack of interest of students in group learning, and (4) the use of learning models and media that are less effective.

The problems that occur above certainly have an impact on student learning outcomes. Based on the results of document studies obtained from class $\mathrm{V}$ teachers in Cluster I, Buleleng District, Buleleng Regency, it was found that the learning outcomes of Grade V students were still low. This can be seen from the average value of the midterm test results (UTS) in the even semester 2019/2020 which is still below the KKM. More clearly, the results of the study of the midterm test scores (UTS) document in science subjects are presented in table 1.

Table 1. Short cut keys for the template

\begin{tabular}{|c|c|c|c|c|c|c|}
\hline \multirow{2}{*}{ No } & School & KKM & Total Students & $\begin{array}{c}\text { Average Mid- } \\
\text { Term }\end{array}$ & Complete & Not Complete \\
\hline 1 & SD N1 Banyuning & 75 & 62 & 64.2 & 28 & 34 \\
\hline 2 & SD N 2 Banyuning & 68 & 35 & 65.83 & 10 & 25 \\
\hline 3 & SD N 5 Banyuning & 65 & 22 & 66.11 & 12 & 10 \\
\hline 4 & SD N 6 Banyuning & 65 & 23 & 66.39 & 15 & 8 \\
\hline
\end{tabular}




\begin{tabular}{|l|c|c|c|c|c|c|}
\hline 5 & SD N 8 Banyuning & 70 & 38 & 66.43 & 17 & 11 \\
\hline \multicolumn{2}{|c|}{ Jumlah } & - & 180 & - & 82 & 88 \\
\hline
\end{tabular}

The success of learning at school will be realized from student learning outcomes. Seeing conditions like this, it is necessary to have research as a solution to optimizing the learning outcomes. Therefore, in order to achieve better and optimal learning outcomes, an effective and efficient learning process is required. Efforts to optimize students' understanding of the material being studied can be done by using models and learning media that are appropriate to the existing problem.

Providing opportunities for students to be more active in participating and active in the learning process will be able to help students improve their learning outcomes. One of the learning models that are thought to be appropriate for the problem of science learning outcomes is the two stay two stray model. Learning with this model will encourage students to actively discuss in groups and work together to discuss a problem. According to Santoso [3] the two stay two stray (TSTS) learning model is a group learning system with the aim that students can work together, increase a sense of responsibility, help each other solve problems and encourage each other to achieve. This model also trains students to socialize well, so that learning will be maximized.

One of the advantages of this model is that it finds a positive atmosphere during learning. Students can freely interact with other students and can build a spirit of cooperation. This TSTS also provides an opportunity for students to ask questions and answer each other to exchange information with students in other groups. As stated [4] that problems regarding students who are less confident about the results they are doing will be resolved because students will be more confident with the results they do because the answers obtained by students have gone through the discussion stage in their own groups and other groups.

The application of the two stay two stray learning model will be better when combined with learning media that involves students playing a more active role in learning. One of the learning media that fits this model is mind mapping media. The use of mind mapping media during learning is expected to be more able to arouse enthusiasm in participating in learning and help students be more skilled in finding their own knowledge.

According to Imas and Berlin [5] mind mapping is a tool that can help the brain think regularly, and is able to map thoughts in the form of real symbols. Mind mapping will help students to understand clearly and systematically about the material to be studied. In addition, mind mapping has the following uniqueness: (1) Central idea, which is the central focus which contains an image or symbol of the problem or information to be mapped; (2) Ideas, after the main idea is determined then the ideas are allowed to flow freely without judgment; (3) Keywords, after the main idea is determined, one keyword is given to make it easier to remember the ideas that have been mapped; (4) Color, used to illuminate and emphasize the importance of an idea; (5) Images and symbols, these are used to highlight ideas and stimulate the brain to form associations and be associated with others. Using mind mapping media can help students better remember and understand the subject matter because it directly involves students in its application. Besides that, it can also increase student creativity. Students will draw, summarize, and record points from the material being studied.

So with this research was carried out with the title The Effect of Two Stay Two Stray (TSTS) Learning Models Providing Mind Mapping on Science Learning Outcomes of Class V Students in Cluster 1, Buleleng District, Academic Year 2019/2020 ". So it can be said that the Two Stay Two Stray learning model providing Mind Mapping is thought to be able to improve student learning outcomes. To prove this, experimental research was conducted entitled "Mind Mapping in Natural Science Learning with the Two Stay Two Stray Model to Improve Student Science Learning Outcomes".

\section{METHOD}

This research was conducted in Cluster I, Buleleng District, Buleleng Regency in grade V students in the even semester (II) of the 2019/2020 school year. This study involved two class groups, namely the experimental group and the control group. The control group is a class that is not given special treatment. While the experimental group is a class that is treated using a two stay two stray learning model providing mind mapping. This type of research is an experimental research that is quasi-experimental (quasi-experimental). Meanwhile, the research design used experimental design Non-Equivalent Post-test Only Control Group Design. The research design can be seen in Figure 1 as follows.

\begin{tabular}{ccc} 
Group & Treatment & Post-test \\
\hline $\mathrm{E}$ & $\mathrm{X}$ & $\mathrm{O}_{1}$ \\
\hline $\mathrm{K}$ & - & $\mathrm{O}_{2}$
\end{tabular}

Figure 1. Non-Equivalent Research Design Post-test Only Control Group Design (Source: Source: modified by [5])

The population is all similar objects in a study that have certain qualities and characteristics. The population 
in this study were all fifth-grade students of SD Gugus I, Buleleng District, 2019/2020 academic year. Overall the population in this study amounted to 180 students. The large number of class V in Cluster I, Buleleng Subdistrict, caused a drawing to be made to take two classes which would be the research subjects.

Samples are part of the population obtained using certain techniques. The selection of samples from all populations was tested through the equivalence test stage. Taking samples from the population using a certain technique called the sample random sampling technique. For this reason, samples taken from the population must be truly representative. The sampling technique used in this study was simple random sampling. The random sample in this study was a class because it was impossible to change an existing class. The sample draw was carried out twice, after obtaining an equivalent class, then a drawing was carried out again to obtain 2 classes that would be used as samples. After obtaining the two samples, then a draw was carried out to determine the control class and the experimental class.

In the lottery process, SD N 5 Banyuning was designated as an experimental group that would be treated using the two stay two stray learning model providing mind mapping and SD N 6 Banyuning was designated as the control class by not using the two stay two stray cooperative learning model.

Data about the learning outcomes of class V students in Cluster I, Buleleng District were collected using the test method. The type of test used in this study is an objective test in the form of multiple-choice tests. This multiple-choice test shows how far the students' mastery of science material in grade V. Each item is given a score of 1 if the student answers correctly (the answer is matched with the answer key that has been made) and for the wrong answer, the student is given a score of 0 .

The test given must be able to measure what the objectives you want to measure are, in this study, namely the student's science learning outcomes. There are two validity tests, namely the content validity test and the item validity test. The content validity test was assessed by two experts (judges) who taught science courses. After that, the results of expert validity were analyzed using the Gregory formula validity test. Meanwhile, item validity is done to measure the accuracy of what the test should measure and how carefully the test measures it. To test the validity of the items used the biserial point correlation formula (rpbi). Based on the results of expert tests that have been carried out, then the multiple-choice test is ready to be tested. The test results are used to determine whether the questions are valid or not to measure student knowledge.

Reliability is the level of consistency or consistency of measurement, to determine the extent to which a measurement can be trusted to produce a steady score, relatively unchanged even though tested in different situations. The reliability test was carried out on the items that had passed the validity test and were declared valid. To calculate the internal consistency reliability the data are dichotomous. The Kuder Richardson 20 (KR-20) formula is used. Koyan [6] states that the distinguishing power of the test is the ability of the test to distinguish between stupid and smart students, where the distinguishing power of a good test ranges from $20 \%$ $80 \%$ or between $30 \%-70 \%$. The number that shows the magnitude of the discriminating power is called the discrimination index, abbreviated as D (large d).

Methods of data analysis in this study using descriptive statistical analysis and inferential statistics. The data collected in this study were the answer data from the science knowledge competency test by grade V SD students. The data that has been collected were analyzed using descriptive statistics and inferential statistics. Descriptive statistical analysis functions to classify data, complete, present, and present processed results. Descriptive statistics used in this study are the mean (mean), median (middle value), mode, and standard deviation (SD), and PAN scale five. Meanwhile, inferential statistical analysis is a way of processing data to test a hypothesis [1]. The inferential statistics used in this study are parametric analysis which includes the normality test of the data distribution and the homogeneity test of variance. In inferential statistical analysis to test the hypothesis, the t-test formula is used. Before testing to get a conclusion, the data obtained needs to be tested for normality, to find out whether the data is normally distributed or not.

The data normality test was analyzed by using the Chi-Square test. The variance homogeneity test was carried out to find the level of homogeneity of the experimental group and the control group. To test the variance homogeneity for the two groups the Fisher's exact formula was used. After the prerequisite test was carried out and the results showed that the data were normally distributed and homogeneous, then the hypothesis was tested. Hypothesis testing in this study was analyzed using the t-test formula. Koyan [10] states that the $\mathrm{t}$-test is used to test the difference in the average value between two groups of correlated samples and independent samples. In addition, this study only compares one independent variable and one dependent variable. Based on the results of the t-test analysis, if $\mathrm{H} 0$ is rejected, $\mathrm{H} 1$ is accepted, it can be interpreted that there is a significant effect of the two stay two stray learning model providing mind mapping on the science learning outcomes of class V students in Cluster I, Buleleng District, Academic year 2019/2020.

\section{RESULTS}

Discussion is the most important part of the entire scientific article content. Purpose Description of the 
results of this study describes the post-test learning outcomes of the experimental group and the control group learning outcomes data. This research was conducted on fifth-grade students of SD Gugus I, Buleleng District. An experimental group is a group of students who are taught the two stay two stray learning models providing mind mapping. In this study, the experimental group consisted of all fifth-grade students of SD Negeri 5 Banyuning. The study was conducted 7 times in face-to-face meetings and 1 post-test at the end of the study. Student science learning outcomes data were obtained through a post-test on 22 students, and the highest score was 28 and the lowest score was 19 . Before the data is presented in the frequency table, first the posttest data range of student science learning outcomes is determined. Based on the results of the descriptive analysis of the science learning outcomes of the experimental group students, it was obtained an average $(M)=24.41$, so it was classified as very good. While the control group is a group of students who are not taught the two stay, two stray learning model, with mind mapping provided. In this study, the control group was all fifth-grade students of SD Negeri 6 Banyuning. Data on student science learning outcomes were obtained through a post-test on 23 students, and the highest score was 24 and the lowest score was 16 . Before the data is presented in the frequency table, the data range is determined first. Based on the calculation results, the average score of students' science learning outcomes in the experimental group was 18.10 so it was classified as good. The summary of the calculation results of the experimental group and the control group is presented in table 2 below.

Table 2. The Summary of Descriptive Statistics Calculation Results of Science Learning Outcomes in the Experiment Group and the Control Group

\begin{tabular}{|l|l|l|}
\hline \multicolumn{1}{|c|}{ Statistics } & \multicolumn{1}{|c|}{$\begin{array}{c}\text { Experiment } \\
\text { Group }\end{array}$} & Control Group \\
\hline Number of Samples & 22 & 23 \\
\hline Mode & 25.50 & 18.83 \\
\hline Median & 24.63 & 19.70 \\
\hline Mean & 24.41 & 20.24 \\
\hline Standard Deviation & 2.79 & 2.56 \\
\hline Variance & 3.38 & 6.57 \\
\hline Maximum Score & 28 & 24 \\
\hline Minimum Score & 19 & 16 \\
\hline Range & 10 & 9 \\
\hline
\end{tabular}

Based on the results of the descriptive analysis in table 2 above, the results of the experimental group and control group science learning are presented in a polygon graph as follows.

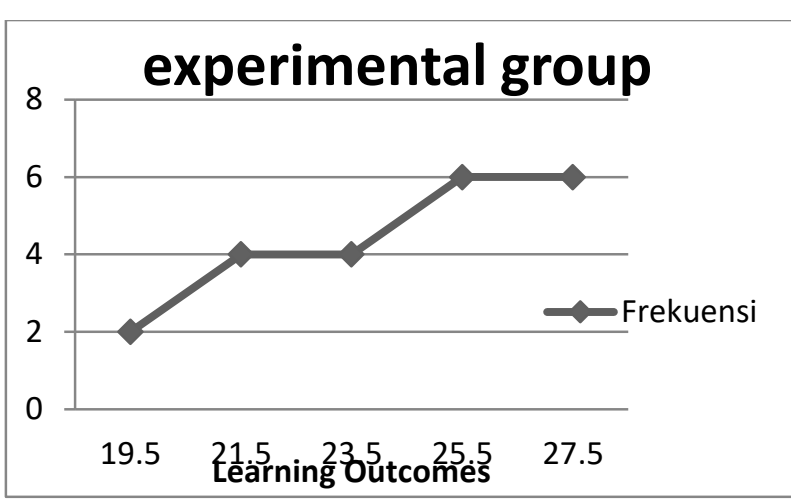

Figure 2. Data on Science Study Results of the Experimental Group

Based on Figure 2 above, it is known that the mode is greater than the median and the median is greater than the mean or Mo> Md> M (25.50> 24.63> 24.41).

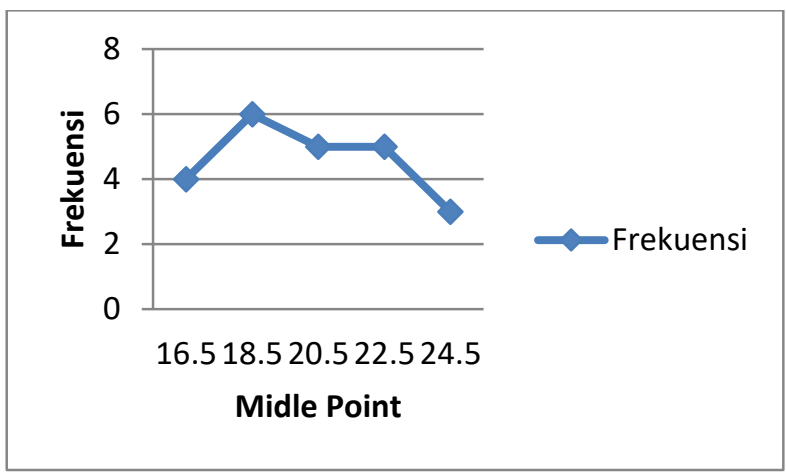

Figure 3. Data on Science Study Results of the Control Group

Based on Figure 3 above, it is known that the median is greater than the median and the median is greater than the mode or Me> Md> Mo (20.24> 19.70> 18.83).

Prior to testing the hypothesis, a prerequisite test was conducted which included a data normality test and a data homogeneity test on student science learning outcomes. The normality test was conducted to determine whether the data were normally distributed or not, which was carried out on the post-test results of students in the experimental group and the control group. The data normality test was performed by using the Chi-Square $(\chi 2)$ test with a significance level of $5 \%$ with $\mathrm{dk}=$ (number of rows - 1). The results of the data normality test are presented in table 3 below.

Table 3. The results of the data normality test

\begin{tabular}{|c|c|c|c|c|}
\hline No & $\begin{array}{c}\text { Learning } \\
\text { Outcomes } \\
\text { Data } \\
\text { Group }\end{array}$ & $\begin{array}{c}\chi^{2} \\
\text { hitung }\end{array}$ & $\begin{array}{c}\text { Critical Value } \\
\text { with a } \\
\text { Significance } \\
\text { Level of 5\% }\end{array}$ & Status \\
\hline 1 & $\begin{array}{l}\text { Experiment } \\
\text { Group }\end{array}$ & 2.65 & 5.99 & Normal \\
\hline
\end{tabular}




\begin{tabular}{|c|l|c|c|c|}
\hline 2 & $\begin{array}{l}\text { Control } \\
\text { Group }\end{array}$ & 2.13 & 5.99 & Normal \\
\hline
\end{tabular}

Based on the results of the data distribution normality test in Table 3 above, the post-test results in the experimental group $\chi^{2}$ count is 2.65 and the post-test results in the control group $\chi 2$ are 2.13 with $\mathrm{db}=\mathrm{k}-3$ at the significance level. 5\%, so the $\chi 2$ table is 5.99 . So the results of the calculation show that the 2 count of the posttest results in the experimental group and the control group is smaller than 2 tables ( 2 count $<2$ tables). So it can be concluded that the science learning outcomes of the experimental group and the control group are normally distributed.

The homogeneity test was carried out on students' science learning outcomes between the experimental group, namely those taught with the two stay two stray learning model providing mind mapping, and the control group which was not taught with the two stay two stray learning model providing mind mapping.

The homogeneity test of variance uses Fisher's test (F) with the test criteria if Fcount <Ftable then the two data groups are declared homogeneous. The summary of the results of the homogeneity test between the experimental group and the control group is presented in table 4 below.

Table 4. The results of homogenity test

\begin{tabular}{|l|l|l|l|l|}
\hline Data source & Varians & $\begin{array}{c}F \\
\text { count }\end{array}$ & $\begin{array}{l}\text { Ftable with a } \\
\text { significance } \\
\text { level of 5\% }\end{array}$ & Status \\
\hline $\begin{array}{l}\text { Post-Test } \\
\text { Experiment } \\
\text { Group } \\
\text { Results }\end{array}$ & 7.78 & 1.18 & 2.06 & $\begin{array}{l}\text { Homo- } \\
\text { gen }\end{array}$ \\
\hline $\begin{array}{l}\text { Post-Test } \\
\text { Experiment } \\
\text { Group } \\
\text { Results }\end{array}$ & 6.57 & & & \\
\hline
\end{tabular}

From the calculation results shown in table 4 , it is known that the Fcount of the science learning outcomes of the experimental group and the control group is 1.18. Compared with Ftable in the denominator $\mathrm{df}=21$ and $\mathrm{df}$ in the denominator 22. $\mathrm{F}$ table $=\mathrm{F}(0.05 ; 21 ; 22)=2.06$. Because $\mathrm{F}_{\text {count }}<\mathrm{F}_{\text {table, }}$, the posttest data has the same or homogeneous variance. These results indicate that the science learning outcomes of the experimental group and the control group are homogeneous.

After calculating the normality test and variance homogeneity test, the results showed that the experimental group data and control group data were normally distributed and homogeneous. So that testing the hypothesis using the t-test with the polled-variance formula. The test criteria are if tcount> ttable then $\mathrm{H} 0$ is rejected and if tcount <ttable then $\mathrm{HO}$ is accepted, obtained in the $t$ distribution table at the 5\% significance level and $d b=(n 1+n 2)-2$. The summary of the t-test calculation results is presented in table 5 below.

Table 5. Results of t-test

\begin{tabular}{|l|c|c|c|c|c|c|}
\hline \multicolumn{1}{|c|}{ Group } & $\mathrm{N}$ & $\mathrm{Db}$ & $\begin{array}{c}\text { Mean } \\
(\mathrm{X} \text { }\end{array}$ & $\begin{array}{c}\text { Varians } \\
(\mathrm{S} 2)\end{array}$ & $\begin{array}{c}\mathrm{t} \\
\text { count }\end{array}$ & $\begin{array}{c}\mathrm{t} \\
\text { tabel }\end{array}$ \\
\hline $\begin{array}{l}\text { Exsperi- } \\
\text { ment }\end{array}$ & 22 & 46 & 24.41 & 7.78 & 5.21 & 2.02 \\
\hline Control & 23 & & 20.24 & 6.57 & & \\
\hline
\end{tabular}

Based on the results of the t-test calculation shown in Table 5, it shows that t_count $=5.21$ and ttable $=2.02$ with $\mathrm{db}=\left(\mathrm{n} \_1+\mathrm{n} \_2\right)-2=43$ at the $5 \%$ significant level. The results of these calculations state $t_{\text {count }}>t_{\text {table }}$ (5.21> 2.02) so that $\mathrm{H} 0$ is rejected and $\mathrm{H} 1$ is accepted. Thus, it is stated that there is a significant difference in science learning outcomes between students who are taught with the two stay two stray learning model providing mind mapping and students who are not taught using the two stay two stray learning model providing mind mapping in class V SD Negeri in Cluster I Buleleng District, Buleleng Regency, Academic Year 2019/2020.

The Two stay two stray models is a model that is implemented in which two group members remain in the group to provide information to other groups and two more members go to other groups for information. The purpose of this model is to build cooperation between students and groups, give a sense of responsibility, and help each other. In learning with this model students are taught to actively carry out group discussions and work together to discuss a problem [7].

The application of the two stay two stray learning model will be better combined with learning media that involve students more actively in learning. One of the learning media that fits this model is mind mapping media. The use of mind mapping media during learning is expected to be more able to arouse enthusiasm in participating in learning and help students be more skilled in finding their own knowledge. Media mind mapping is a tool that can help the brain think regularly and is able to map thoughts in the form of real symbols [8].

Learning by applying the two stay two stray model with mind mapping provides an opportunity for all students to appear active and confident in participating in learning activities. In TSTS cooperative learning, a positive atmosphere is found, where students can be accepted by other students and can build a spirit of cooperation. TSTS also provides an opportunity for students to ask and answer questions to exchange information with students in other groups so that the 
problem of "students who are not confident about the results they are doing" will be resolved because students will be more confident with the results they do because of the answers they get. Students have gone through the discussion stage in the group itself and other groups [4].

The findings in the experimental group are that learning activities become more fun because students learn enthusiastically and actively. Students can gradually understand the concepts and materials of science with positive and motivational learning nuances. The use of mind mapping media in learning activities really helps students explain and understand the material in a more structured manner. Students can exchange opinions with their groups, explain and demonstrate the results of their discussions to other groups so that students are used to delivering material and receiving suggestions and input from friends and from the teacher.

The science learning outcomes of the experimental group increased after participating in learning with a two stay two stray model providing mind mapping because there were differences in behavior in student learning activities. The findings in the experimental group were that there were more student learning activities than teacher activities, students found understanding because there was enough learning experience for them to communicate and conclude the material being studied. Students are given the opportunity to communicate and interact socially with their friends to achieve learning goals, while the teacher acts as a motivator and facilitator of student activities.

The students' conditions in the experimental group differed from those of the control group students. Students who are taught not using the two stay two stray learning model providing mind mapping tend to be passive, due to the lack of media used by the teacher to make students interested in the learning process. Students only listen to the teacher's explanation, so that teachercentered learning. Student activities in the classroom mostly listen to the teacher's explanation. When the teacher asked questions, only a few students were brave and able to answer the questions. This atmosphere makes students feel bored quickly with the learning that is taking place. The two stay two stray learning model providing mind mapping is very helpful for students in understanding the learning material. Learning by applying the two stay two stray learning model with mind mapping can increase activity and cooperation so that learning outcomes increase.

The findings of this study are reinforced by research by Harahap, Kholilah Amriani, and Edy Surya [9] which states that the TSTS model can help students understand subject matter marked by an increased average student learning achievement. Through the Two Stay Two Stray (TSTS) cooperative learning model, students can learn to be enthusiastic in integrating various knowledge and skills that can increase students' courage and activeness.
The same thing was stated by Surki [10] which stated that TSTS was able to increase students' persistence, tenacity, and independence in learning Economics so that there was an increase in motivation and learning outcomes of class XI IPS -SMA Negeri Unggul Dharmasraya. Thus, the Two Stay Two Stray learning model providing mind mapping can be recommended in learning activities

\section{CONCLUSION}

Based on the results of research and analysis, it can be concluded that there is an influence on the use of a two stay two stray learning model with mind mapping on science learning outcomes in class V SD Negeri students in Cluster I, Buleleng District, Buleleng Regency, 2019/2020 Academic Year. The suggestions that can be conveyed by researchers are as follows. To students, it is recommended that students in the learning process gain a more active and interesting, fun, and meaningful learning experience and can improve student science learning outcomes. Teachers, it is advisable for teachers to add information and insight into more creative learning innovations to provide facilities in the form of learning resources and greater opportunities for students in learning by using the two stay two stray learning model providing mind mapping so as to create a pleasant learning atmosphere and improve student learning outcomes. For schools, it is recommended that schools be able to provide changes in the learning process so that school goals can be achieved and can improve school achievement. To other researchers, it is suggested that the research results be used as a reference for carrying out further research and finding innovations in other meaningful learning activities for students.

\section{REFERENCES}

[1] W. Suwitra, Belajar dan Pembelajaran, Singaraja: Universitas Pendidikan Ganesha, 2014.

[2] P. N. Riastini, et. al., Pembelajaran IPA SD, Singaraja: Universitas Pendidikan Ganesha, 2016.

[3] Y. I. Purnamasari, M. Hadeli L., Sofia, Peningkatan Keaktifan Dan Hasil Belajar Siswa Dengan Menggunakan Model Pembelajaran Two Stay Two Stray (TSTS) di Kelas XI SMA Tri Dharma Palembang, Jurnal Penelitian Pendidikan Kimia, Volume 4, Nomor 1, Mei 2017, pp. 70-78.

[4] A. Istiqoida, et. al., Penerapan Model Pembelajaran Kooperatif Tipe Two Stay Two Stray (TSTS) Untuk Memperbaiki Proses Pembelajaran Dan Meningkatkan Hasil Belajar Matematika Kelas VIIIE SMP Negeri 18 Pekanbaru, Program Studi Pendidikan Matematika Fakultas Keguruan dan Ilmu Pendidikan Universitas Riau, 2017. 
[5] I. Aprinawati, Penerapan Model Peta Pikiran (Mind Mapping) Untuk Meningkatkan Keterampilan Menulis Karangan Narasi Siswa Kelas IV B SD Negeri 007 Bangkinang, Dosen Universitas Pahlawan Tuanku Tambusai, Esj Volume 7, No. 1, Juni 2017, pp. 19-31.

[6] I W. Koyan, Asesmen Dalam Pendidikan, Singaraja: Undiksha Press, 2011.

[7] H. Chotimah, Peningkatan Keterampilan Diskusi Siswa Kelas S SMAN 1 Pleret, Bantul Melalui Model Pembelajaran Two Stay Two Stray, Jurnal Ilmiah Edukasi \& Sosial, Volume 8, Nomor 1, Maret 2017, pp. 29-40.

[8] I. Aprinawati, Penerapan Model Peta Pikiran (Mind Mapping) Untuk Meningkatkan Keterampilan Menulis Karangan Narasi Siswa Kelas IV B SD Negeri 007 Bangkinang, Dosen Universitas Pahlawan Tuanku Tambusai, Esj Volume 7, No. 1, Juni 2017, pp. 19-31.

[9] K. A. Harahap, and S. Edy, Application of Cooperative Learning Model with Type of Two Stay Two Stray to Improve Results of Mathematics Teaching, International Journal of Sciences: Basic and Applied Research (IJSBAR), 2017, pp. 156165.

[10] S. Sukri, Peningkatan Motivasi dan hasil Belajar Siswa Melalui Model Pembelajaran Kooperatif Two Stay Two Stray, Jurnal Inovasi Pendidikan Ekonomi (JIPE) 9(2) (2019) 152-161.

[11] Law of the Republic of Indonesia Number 20 of 2003, Tentang Sistem Pendidikan Nasional, Jakarta: Sinar Grafika, 2007.

[12] I W. Koyan, Statistik Pendidikan Teknik Analisis Data Kuantitatif, Singaraja: Undiksha Press, 2012. 